Commonwealth Education Conference held in July 1959. The Advisory Committee is therefore studying a first list of some twenty-five scientific and technical text-books for issue in low-priced editions to universities and college libraries, instructors and individual students. Initially the arrangement will be applied to India. It is hoped that the books will be made available for distribution in India this winter.

\section{The Proterozoic in the U.S.S.R.}

THe rocks belonging to the Upper Pre-Cambrian or Proterozoic group in China, named by Grabau as belonging to the Sinian system, during the past two decades have been proved to be very abundant in the Urals and other parts of the U.S.S.R. In the absence of characteristic fossils which would allow a correlation with the Sinian, the prominent Soviet geologist, N. S. Shatsky, in 1945 proposed the name of Rhiphaean system, from Rhiphaean Mountains, an old name for the Ural Mountains. Recent work on the determination of the absolute age of these formations, as presented by B. M. Keller (Priroda, 9, 30; 1959), gives the following figures: Taratash gneiss underlying Rhiphaean series, 1,100 m.y. ; uppermost Rhiphaean deposits-Inzer sandstone, 865 m.y.; Serdobian suite rocks, 680 m.y. ; Larminarites suite, 540-560 m.y. Thus, the Rhiphaean system may be demarcated in age as $1,100-500 \mathrm{~m} . \mathrm{y}$. It is divided into the Upper Timanian suite and the Lower Yakutian suite. The rocks of the Yakutian suite are characterized by a peculiar calcareous alga of a stromatolite type named Conophyton, while in the Timanian suite a branching alga named Collenia is found. These two algal types form very thick layers of limestone, but no remains of animals have as yet been found in these rocks. While V. P. Maslov studied these algae, S. N. Naumova has discovered spores of land or, more probably, of shore plants, which was rather unexpected. In Siberia, especially in the region of the Lake Baikal, the Upper Rhiphaean strata are folded and intruded by granite, and so N. S. Shatsky applied the name Baikalian to the orogenotic and magmatic epoch of this age. Within the area of the present Russian platform the Baikalian tectonic movements led to the production of three major shields-Baltic, Sarmatian and Tartarianand two major geosynclines-Scandinavian and Uralian. The geosynclinal Rhiphaean sediments were deposited in well-marked sedimentary cycles, beginning with coarse conglomerates and breccia and finishing with fine-grained sediments.

\section{Excavations at Dzibilchaltun in Yucatan}

AN account of excavations carried out during three seasons by the National Geographic Society and Tulane University at Dzibilchaltun in north-western Yucatan, Mexico, has now been published (Proc. Amer. Phil. Soc., 104, No. 3 ; June 15, 1960). Little has been known about the early phases of culture in this part of the world, and the exploration of some large buildings and temples and the determination of a definite stratigraphy are of great interest. To the prehistorian the date of the constructions (round about A.D. 500) might seem somewhat modern, but much hitherto unknown information of the earlier cultures in those little explored areas is here unfolded.

\section{Nature Conservancy Awards for 1960}

The Nature Conservancy announces the following awards of research studentships for postgraduate training in ecology, tenable for periods up to three years at the universities shown : Botany : Miss M. C. Anderson (Cambridge), P. E. Gibbs (Liverpool), Miss M. M. MeGrath (University College of North Wales, Bangor), J. G. Pusey (Oxford); Zoology: R. A. Avery (Bristol), D. E. Baird (Oxford), P. P. G. Bateson (Cambridge), Miss V. Healey (Manchester), D. J. Hobden (Southampton), W. W. Murdock (Oxford), Miss M. A. Murphy (Manchester), D. C. Seel (Oxford), J. B. Whittaker (Durham); Geography: Miss J. Wain (London); Diploma Course in Conservation and Ecology at University College, London: G. P. Allen, J. M. Davidson, K. East, A. J. Kerr, Miss J. J. Rowe, D. A. White.

\section{The Beilby Medal and Prize, 1961}

Since 1930, at intervals of one or more years, awards have been made by the administrators of the Sir George Beilby Memorial Fund, representing the Royal Institute of Chemistry, the Society of Chemical Industry and the Institute of Metals. In 1958 two awards, each of 150 guineas, were made. It was then agreed that no further award would be made before 1960. The administrators have now decided that henceforth each award shall consist of a gold medal as well as a substantial sum of money, and shall be known as "The Beilby Medal and Prize" and specified as being "For Advancement in Science and Practice". Such an award will be offered at intervals of two years, but more than one may be made on the same occasion if there are several candidates of sufficiently outstanding merit. Consideration will be given in due course to the making of an award (or awards) from the Fund in 1961, for outstanding work on the development and application of scientific principles in any field related to the special interests of Sir George Beilby, namely, in chemical engineering, fuel technology or metallurgy. Applications must be submitted not later than December 31, 1960, by letter addressed to the Convenor of the Administrators, Sir George Beilby Memorial Fund, Royal Institute of Chemistry, 30 Russell Square, London, W.C.1.

\section{The Scientific Instrument Manufacturers' Associa- tion}

THE following have been elected officers and council of the Scientific Instrument Manufacturers' Association of Great Britain for the year 1960-61 : President, Mr. G. C. Ottway (W. Ottway and Co., Ltd.); Vice-Presidents, Mr. A. W. Jones (Fleming Radio (Developments), Ltd.), and Mr. L. A. Woodhead (Conor Instruments, Ltd., and retiring president). Honorary Treasurer, Mr. A. W. A. Rundle (A. Gallenkamp and Co., Ltd.); Honorary Secretary, Mr. E. R. Ponsford (Solartron Electronic Group, Ltd.) ; Council Members, Mr. S. T. Pickoring (Chance Pilkington Optical Works), Mr. G. M. Sisson (Sir Howard Grubb Parsons and Co., Ltd.), Mr. G. S. Sturrock (Kelvin and Hughes, Ltd.) and Mr. R. Foxwell (The Wayne Kerr Laboratories, Ltd.).

\section{University News: Churchill College, Cambridge}

Mr. C. St. J. Wilson, of Corpus Christi College, has been elected to a fellowship as from October 1 . The following elections to junior research fellowships from October 1 are announced : R. A. Y. Jones, of Clare College; A. O. Gilchrist, of Trinity Hall (Sydney Harvey Fellowship); C. B. Cottrell, University of the Witwatersrand and Queens' College 